\title{
ACUTE MYOCARDIAL INFARCTION IN OLDER ADULT PATIENTS
}

\section{Infarto agudo do miocárdio em pacientes idosos}

\author{
Marcia Moura Schmidta, ${ }^{\mathrm{a}}$, Cristina Klein Weber ${ }^{\mathrm{a}, \mathrm{b}}$ (1), \\ Carlos Antonio Mascia Gottschalla,b $\mathbb{1}$, Alexandre Schaan de Quadros ${ }^{\mathrm{a}, \mathrm{b}}$
}

\begin{abstract}
OBJECTIVES: To assess clinical and coronary angiographic characteristics, previous medical history, and clinical course, by age group, in older adults after myocardial infarction who underwent primary percutaneous coronary intervention (pPCI). METHODS: Single-center, cohort study that enrolled all patients with ST-segment elevation myocardial infarction who underwent $\mathrm{pPCl}$ at a specialized cardiology reference center in the South of Brazil. Older adults were defined as age $\geq 60$ years, as set out in Brazilian legislation. Patients in the following age groups were compared: 60 to 64 years, 65 to 69 years, 70 to 74 years, 75 to 79 years, and $\geq 80$ years. Patients' clinical course was assessed at initial hospital admissions and after 2 years of clinical follow-up. Data were analyzed using SPSS 19, and significance was established at $p<0.05$. RESULTS: From December 2015 to December 2018, a total of 636 patients were enrolled consecutively. Angiographic success rates were around $90 \%$ in all age groups. There were no differences in medications used, except for glycoprotein Ilb/llla inhibitors, which were more frequently used in patients of lower age groups. Older patients had more in-hospital acute renal failure and higher in-hospital mortality. Predictors of mortality were age over 75, chronic renal failure, need for ventilatory support, severe arrhythmia, and sepsis. CONCLUSIONS: $\mathrm{pPCl}$ in older adult patients is a safe procedure with a high success rate.

KEYWORDS: myocardial infarction; angioplasty; critical care; health services for the aged; aged.
\end{abstract}

OBJETIVOS: Avaliar características clínicas e angiográficas, história clínica pregressa e evolução clínica, por faixa etária, em idosos submetidos a intervenção coronária percutânea primária (ICPp) após infarto do miocárdio. METODOLOGIA: Estudo de coorte, de centro único, que incluiu todos os pacientes com infarto do miocárdio com supradesnivelamento do segmento ST submetidos ICPp em um centro de referência especializado em cardiologia no sul do Brasil. Os idosos foram definidos como aqueles com idade $\geq 60$ anos, conforme estabelecido na legislação brasileira. Os pacientes nas seguintes faixas etárias foram comparados: 60 a 64 anos, 65 a 69 anos, 70 a 74 anos, 75 a 79 anos e $\geq 80$ anos. 0 curso clínico dos pacientes foi avaliado nas admissões hospitalares iniciais e após 2 anos de acompanhamento clínico. Os dados foram analisados usando o SPSS 19, e p < 0,05 foi considerado significativo. RESULTADOS: De dezembro de 2015 a dezembro de 2018, 636 pacientes foram incluídos consecutivamente. As taxas de sucesso angiográfico foram de cerca de $90 \%$ em todas as faixas etárias. Não houve diferenças nos medicamentos utilizados, com exceção dos inibidores da glicoproteína IIb/Illa, que foram mais frequentemente utilizados em pacientes em faixas etárias mais baixas. Pacientes mais velhos apresentaram mais insuficiência renal aguda intra-hospitalar e maior mortalidade hospitalar. Os preditores de mortalidade foram: idade superior a 75 anos, insuficiência renal crônica, necessidade de suporte ventilatório, arritmia grave e sepse. CONCLUSÕES: O ICPp em pacientes idosos é um procedimento seguro e com alta taxa de sucesso.

PALAVRAS-CHAVE: infarto do miocárdio; angioplastia; cuidados críticos; serviços de saúde para idosos; idoso.

alnstituto de Cardiologia do Rio Grande do Sul, Fundação Universitária de Cardiologia - (IC/FUC) Porto Alegre (RS), Brazil.

'Programa de Pós Graduação em Ciências da Saúde: Cardiologia/ Fundação Universitária de Cardiologia - Porto Alegre (RS), Brazil.

Corresponding data

Marcia Moura Schmidt - Instituto de Cardiologia do Rio Grande do Sul, Fundação Universitária de Cardiologia - (IC/FUC) - Avenida Princesa Isabel, 395 Santana - CEP: 90040-371- Porto Alegre (RS), Brazil - E-mail: mouramarcia050@gmail.com

Received on: 01/29/2020. Accepted on: 04/07/2020

DOI: 10.5327/Z2447-212320202000011 


\section{INTRODUCTION}

Brazil is going through a demographic transition process. The population ageing increases the rates of chronic diseases and comorbidities, increasing, as a consequence, the demand for health services and requiring the recognition of the needs of the population of this age group. ${ }^{1}$ Cardiovascular diseases are among the main causes of morbidity and mortality worldwide, with rates in Brazil and the United States of $28 \%$ and $31 \%$, respectively. ${ }^{2,3}$ Percutaneous coronary revascularization is increasingly indicated for older adults, both for stable coronary artery disease and for acute coronary syndromes. ${ }^{4}$

It is estimated that 60 to $65 \%$ of ST-segment elevation myocardial infarctions (STEMI) occur in patients over the age of $60 . .^{5} \mathrm{~A}$ small proportion of the participants in large clinical trials are older adults and these patients have atypical presentations, including silent or unrecognized acute myocardial infarction and left bundle branch block. ${ }^{5}$ Compared with the younger population, older adult patients submitted to percutaneous angioplasty present more frequently with diffuse disease, ventricular dysfunction, acute coronary syndromes, and comorbidities such as renal failure, strokes, and peripheral arterial disease, making their clinical status less favorable. These characteristics make it more difficult to assess the results of interventions in this age group.$^{6-8}$

There are no contemporary studies conducted in Brazil that analyze the clinical and angiographic characteristics and clinical outcomes of older adults who underwent primary percutaneous coronary intervention. The objective of the present study was to record, analyze, and compare these characteristics as age increases in patients who had a recent infarction and were treated with primary percutaneous coronary intervention (pPCI) at a specialized cardiology reference center in the South of Brazil.

\section{METHODS}

Cross-sectional, single-center cohort study that enrolled all patients with ST-segment elevation myocardial infarction (STEMI) who underwent pPCI at a specialized cardiology reference center in Southern Brazil from December 2015 to December 2018. The study was approved by the institutional Research Ethics Committee and all patients signed an informed consent form. Patients were followed for 30 days, 1 year and 2 years by medical records and telephone calls to determine their health status.

Patients were considered for inclusion in the study if they were admitted via the emergency department at our institution by STEMI. Older adults were defined as $\geq 60$ years, as set out in the Brazilian legislation. ${ }^{9}$
According to the V Brazilian Cardiology Society Guidelines on Treatment of ST-Segment Elevation Acute Myocardial Infarction, ${ }^{10}$ diagnosis of STEMI was defined as raised levels of cardiac markers (with at least one result over the 99th percentile) followed by a drop off, constituting an enzyme curve. Additionally, at least one of five criteria had to be present to confirm a diagnosis of STEMI:

- symptoms of myocardial ischemia;

- abnormalities of the ST segment/T wave or new left bundle branch block;

- development of pathological Q waves on the ECG;

- loss of viable myocardial muscle or abnormalities of segmental motion seen on an imaging examination;

- identification of an intracoronary thrombus by angiography or autopsy.

Exclusion criteria were chest pain lasting more than 12 hours or patient refusal to participate.

Primary percutaneous coronary intervention (pPCI) was performed as recommended in the literature. All patients were medicated at admission with $300 \mathrm{mg}$ acetylsalicylic acid and 300 to $600 \mathrm{mg}$ of clopidogrel or $180 \mathrm{mg}$ of ticagrelor. Unfractionated heparin (60 to $100 \mathrm{U} / \mathrm{kg}$ ) was administered before $\mathrm{pPCI}$ in the emergency room or the Cath Lab. Technical aspects of the procedure, such as stents characteristcs and number, use of devices and use of glycoprotein IIb/ IIIa inhibitors were decided by the interventional physician responsible for PCI. ${ }^{11}$ Patients were interviewed during their hospital stay in order to obtain information on previous history and risk factors. Clinical evolution were obtained from the hospital system.

Criteria used to define risk factors were as follows: smoking: regular cigarette smoking; hypertension $(\mathrm{H})$; prior diagnosis of hypertension and/or use of antihypertensive drugs; diabetes mellitus (DM): prior diagnosis of DM and/or use of drugs to treat diabetes, fasting Glycemia $\geq 126 \mathrm{mg} / \mathrm{dL}$, Glycemia 2 hours after a Glucose challenge $\geq 200 \mathrm{mg} / \mathrm{dL}$, or Glycated Hemoglobin (HbA1c) $\geq 6.5 \%$; dyslipidemia (DSLP): fasting serum cholesterol exceeding $240 \mathrm{mg} / \mathrm{dL}$, prior diagnosis of DSLP, and/or use of antihyperlipidemic medication; family history for coronary artery disease: AMI or sudden death among first-degree relatives.

Data were analyzed using SPSS for Windows. Significance was established at $\mathrm{p}<0.05$. Medians and interquartile ranges were calculated for ages. The study sample was classified into five age groups: 60 to $64 ; 65$ to $69 ; 70$ to 74,75 to 79 , and 80 or older. Quantitative variables were expressed as means and standard deviations and compared with oneway ANOVA or the Kruskal-Wallis test. Categorical variables 
were expressed as absolute and relative frequencies and analyzed with the $\chi^{2}$ test. Multiple logistic regression was used to identify predictors of mortality and Kaplan Meier curves were plotted to illustrate event-free survival by age group.

\section{RESULTS}

From December 2015 to December 2018, 1274 patients underwent primary percutaneous coronary intervention, of which 636 were over 60 years of age and were included in the present analysis. Regarding the age groups analyzed, 202 patients were aged from 60 to 64 years old, 157 patients from 65 to 69 years, 125 patients from 70 to 74 years, 81 , from 75 to 79 , and 71 patients were 80 years or older. With regard to clinical characteristics, we observed that younger patients were smokers more frequently and had a family history of coronary artery disease, while the oldest patients had hypertension and had left bundle branch block (LBBB) more frequently than other patients. Considering the medical history, the oldest patients had more strokes, heart failure, and chronic renal failure. There was no difference in the prevalence of previous AMI, previous percutaneous coronary interventions, or coronary artery bypass graft.
The angiographic profiles of patients were very similar in all groups, with no difference in the percentages of patients with multiarterial involvement. Older patients had coronary calcification more frequently. There was no significant difference between the study groups in culprit vessel IAM, percentage of left main disease, or bifurcations lesions. Need for an intra-aortic balloon or pacemaker did not differ according to age. Angiographic success rates were similar in all age groups. The door-to-balloon time, however, was longer among patients over the age of 80 (Table 1). It can be observed in Table 2 that medications used were also similar in all age groups, with the exception of Glycoproteins IIb/IIIa inhibitors, which were more frequently used in younger patients.

During hospital stay (Table 3), there were no significant differences in percentages of severe arrhythmia or sudden death averted, bleeding, sepsis, or need for ventilatory support. However, acute kidney injury (AKI) was more frequent among the older patients. In-hospital mortality was higher among the older patients.

The patients were followed for $328 \pm 280$ days. We found $6 \%$ and $8 \%$ losses in 1 and 2 years of follow-up, respectively. The overall mortality was $10.2 \%$ and higher among the patients in the 75- to 79-year-old group (25\%).

Table 1 Coronary angiographic characteristics of 636 older adults by age group.

\begin{tabular}{|c|c|c|c|c|c|c|}
\hline Characteristics & $\begin{array}{c}\text { 60-64 years } \\
n=202\end{array}$ & $\begin{array}{c}\text { 65-69 years } \\
n=157\end{array}$ & $\begin{array}{c}70-74 \text { years } \\
n=125\end{array}$ & $\begin{array}{c}\text { 75-79 years } \\
n=81\end{array}$ & $\begin{array}{c}\geq 80 \text { years } \\
n=71\end{array}$ & $\mathbf{p}$ \\
\hline Triple vessel disease, n (\%) & $47(23.40)$ & $44(28.60)$ & $32(25.80)$ & $23(28.70)$ & $24(34.80)$ & 0.13 \\
\hline \multicolumn{7}{|l|}{ Culprit vessel } \\
\hline$A D, n(\%)$ & 89 (44.90) & $61(39.60)$ & $49(40.20)$ & $27(34.20)$ & $32(46.40)$ & \multirow{6}{*}{0.37} \\
\hline CX, n (\%) & $19(9.60)$ & $21(13.60)$ & $17(13.90)$ & $9(11.40)$ & $4(5.80)$ & \\
\hline $\mathrm{RC}, \mathrm{n}(\%)$ & 85 (42.90) & $71(46.10)$ & $49(40.20)$ & 39 (49.40) & $33(47.80)$ & \\
\hline LCA, n (\%) & $3(1.50)$ & 0 & $2(1.60)$ & $1(1.30)$ & 0 & \\
\hline Mammary, n (\%) & - & - & - & $1(1.30)$ & 0 & \\
\hline Saphenous Bypass, n (\%) & $2(1.00)$ & $1(0.60)$ & $5(4.10)$ & $2(2.50)$ & 0 & \\
\hline LMD, n (\%) & $6(3.00)$ & $4(2.60)$ & $10(8.10)$ & $4(5.00)$ & $3(4.30)$ & 0.22 \\
\hline Bifurcation, n (\%) & $8(4.00)$ & $6(3.90)$ & $8(6.60)$ & $2(2.50)$ & $3(4.40)$ & 0.92 \\
\hline Calcification, n (\%) & $6(3.00)$ & $11(7.10)$ & $9(7.40)$ & $11(13.80)$ & $16(23.50)$ & $<0.001$ \\
\hline Vessel diameter, mm & $3.13 \pm 0.44$ & $3.09 \pm 0.59$ & $3.12 \pm 0.40$ & $3.12 \pm 0.40$ & $3.16 \pm 0.60$ & 0.85 \\
\hline Length of lesion, mm & $24.85 \pm 12.61$ & $26.00 \pm 11.90$ & $24.36 \pm 11.12$ & $24.56 \pm 11.12$ & $25.68 \pm 11.48$ & 0.51 \\
\hline Femoral access, n (\%) & $44(22.30)$ & $33(21.40)$ & $34(28.10)$ & $24(30.80)$ & $23(33.30)$ & 0.03 \\
\hline Pre-dilatation, n (\%) & $146(75.60)$ & $106(70.70)$ & $85(70.20)$ & $53(74.60)$ & $54(77.10)$ & 0.92 \\
\hline Stenting, n (\%) & $188(94.50)$ & 139 (92.10) & $105(86.80)$ & $67(91.80)$ & $63(88.70)$ & 0.07 \\
\hline Bare-metal Stent, n (\%) & $115(61.20)$ & $76(55.10)$ & $59(57.80)$ & $40(60.60)$ & $35(56.50)$ & 0.67 \\
\hline Post dilatation, n (\%) & $71(36.40)$ & $54(36.20)$ & $36(29.80)$ & $27(37.00)$ & $22(31.40)$ & 0.43 \\
\hline
\end{tabular}


Table 1 Continuation.

\begin{tabular}{l|c|c|c|c|c|c} 
Characteristics & $\begin{array}{c}60-64 \text { years } \\
\mathrm{n}=202\end{array}$ & $\begin{array}{c}65-69 \text { years } \\
\mathrm{n}=157\end{array}$ & $\begin{array}{c}70-74 \text { years } \\
\mathrm{n}=125\end{array}$ & $\begin{array}{c}75-79 \text { years } \\
\mathrm{n}=81\end{array}$ & $\begin{array}{c}\geq 80 \text { years } \\
\mathrm{n}=71\end{array}$ \\
\hline IAB, $\mathrm{n}(\%)$ & $13(6.40)$ & $5(3.20)$ & $6(4.80)$ & $2(2.60)$ & $5(7.40)$ & 0.78 \\
\hline Pacemaker, $\mathrm{n}(\%)$ & $10(5.00)$ & $12(7.80)$ & $9(7.50)$ & $5(6.40)$ & $5(7.10)$ & 0.54 \\
\hline TIMI 3 Post, $\mathrm{n}(\%)$ & $184(93.40)$ & $132(89.80)$ & $109(91.60)$ & $62(87.30)$ & $60(92.30)$ & 0.71 \\
\hline Angiographic Success, $\mathrm{n}(\%)$ & $183(93.40)$ & $131(89.70)$ & $105(89.70)$ & $60(87.00)$ & $60(92.30)$ & 0.50 \\
\hline Complications, $\mathrm{n}(\%)$ & $25(12.40)$ & $18(11.50)$ & $19(22.90)$ & $12(14.80)$ & $9(12.70)$ & 0.59 \\
\hline Door-to-Balloon, minutes & $0: 44[0: 33-0: 72]$ & $0: 52[0: 37-0: 65]$ & $0: 48[0: 39-0: 73]$ & $0: 40[0: 37-0: 61]$ & $0: 56[0: 43-0: 87]$ & 0.007 \\
\hline EF\% & $51.30 \pm 12.40$ & $51.00 \pm 15.60$ & $52.70 \pm 13.60$ & $53.80 \pm 13.10$ & $49.00 \pm 14.00$ & 0.84 \\
\hline
\end{tabular}

AD: anterior descending artery; CX: circumflex; RC: right coronary; LCA: Left main coronary artery; LMD: left main disease; IAB: intra-aortic balloon; TIMI: thrombolysis in myocardial infarction grade = myocardial perfusion; EF: left ventricle ejection fraction.

Table 2 Medications used by 636 older adults.

\begin{tabular}{l|c|c|c|c|c|c} 
Medication & $\begin{array}{c}60-64 \text { years } \\
\mathrm{n}=202\end{array}$ & $\begin{array}{c}65-69 \text { years } \\
\mathrm{n}=157\end{array}$ & $\begin{array}{c}70-74 \text { years } \\
\mathrm{n}=125\end{array}$ & $\begin{array}{c}75-79 \text { years } \\
\mathrm{n}=81\end{array}$ & $\begin{array}{c}\geq 80 \text { years } \\
\mathrm{n}=71\end{array}$ \\
\hline Clopidogrel $600 \mathrm{mg}, \mathrm{n}(\%)$ & $186(93.00)$ & $146(94.20)$ & $112(91.10)$ & $73(91.30)$ & $65(95.60)$ & 0.88 \\
\hline Ticagrelor $180 \mathrm{~g}, \mathrm{n}(\%)$ & $7(3.50)$ & $6(3.90)$ & $2(1.60)$ & $2(2.50)$ & $2(2.90)$ & 0.52 \\
\hline Heparin Bolus, $\mathrm{n}(\%)$ & $175(87.50)$ & $136(88.30)$ & $104(86.00)$ & $70(89.70)$ & $58(84.10)$ & 0.59 \\
\hline ASA, $\mathrm{n}(\%)$ & $198(99.00)$ & $153(98.70)$ & $121(98.40)$ & $78(97.50)$ & $67(98.50)$ & 0.41 \\
\hline $\begin{array}{l}\text { Glycoprotein IIbllla } \\
\text { Inhibitors, } \mathrm{n}(\%)\end{array}$ & $36(17.80)$ & $24(15.30)$ & $21(16.80)$ & $7(8.60)$ & $5(7.00)$ & 0.01 \\
\hline
\end{tabular}

ASA: acetylsalicylic acid.

Table 3 Mortality and in-hospital events in 636 older adults.

\begin{tabular}{|c|c|c|c|c|c|c|}
\hline Events & $\begin{array}{c}60-64 \text { years } \\
n=202\end{array}$ & $\begin{array}{c}65-69 \text { years } \\
n=157\end{array}$ & $\begin{array}{c}70-74 \text { years } \\
n=125\end{array}$ & $\begin{array}{c}\text { 75-79 years } \\
n=81\end{array}$ & $\begin{array}{c}\geq 80 \text { years } \\
n=71\end{array}$ & $\mathbf{p}$ \\
\hline \multicolumn{7}{|l|}{ In hospital } \\
\hline Severe arrhythmia, n (\%) & $15(7.40)$ & $11(7.10)$ & $10(8.30)$ & $9(11.30)$ & $6(9.00)$ & 0.37 \\
\hline Bleeding, n (\%) & $3(1.50)$ & $2(1.30)$ & $3(2.40)$ & $3(3.80)$ & 0 & 0.23 \\
\hline Sepsis, n (\%) & $10(5.00)$ & $4(2.50)$ & $9(7.40)$ & $7(8.80)$ & $4(6.00)$ & 0.20 \\
\hline Ventilatory support, n (\%) & $23(11.40)$ & $18(11.50)$ & $21(17.10)$ & $12(15.00)$ & $8(11.90)$ & 0.41 \\
\hline Acute kidney injury, n (\%) & $13(6.50)$ & $8(5.10)$ & $9(7.50)$ & $13(16.30)$ & $6(9.00)$ & 0.04 \\
\hline Death, n (\%) & $14(6.90)$ & $9(5.70)$ & $13(10.70)$ & $14(17.50)$ & $11(16.20)$ & 0.001 \\
\hline
\end{tabular}

Table 4 shows the independent predictors of mortality in this sample, specifically: age $\geq 75$ years, female, chronic renal failure, need for ventilatory support, and occurrence of severe arrhythmia and sepsis on admission. Chronic kidney failure (CKF) and severe arrhythmia led to a fourfold increase in the risk of death and sepsis increased risk by 13 times.

In Figure 1, it can be observed that although mortality was higher among patients over 75 , event-free survival was still around $80 \%$ during late clinical follow-up.

\section{DISCUSSION}

In this report, we analyzed a consecutive cohort of older adult patients with STEMI submitted to pPCI in a high-volume, tertiary cardiology center. The main findings were that older adults had similar rates of success in the $\mathrm{pPCI}$ procedure when compared to younger individuals, but the older patients had acute kidney injury more frequently and had higher mortality in the follow-up. We believe that this is an important piece of information, because it confirms that older STEMI patients have a higher risk 
of adverse clinical events, but it shows that contemporary pPCI treatment has similar results in these patients when compared to younger individuals.

Within this perspective, a sub-analysis from 5475 STEMI patients in the APEX TRIAL study ${ }^{12}$ showed that patients over 75 years had less angiographic success than their younger counterparts. Although this analysis was derived from a large sample, its results may not be representative of the current daily practice, as it was published in 2011. Since then, several significant developments have occurred in the field, such as newer and more potent antiplatelet drugs, the widespread

Table 4 Multiple logistic regression for predictors of mortality.

\begin{tabular}{l|c|c|c}
\hline Characteristics & Odds & $95 \% \mathrm{Cl}$ & $\mathrm{p}$ \\
\hline Age $\geq 75$ & 4.47 & $1.19-16.74$ & 0.03 \\
\hline Male & 0.36 & $0.14-0.96$ & 0.04 \\
\hline CHF & 2.44 & $0.79-7.61$ & 0.12 \\
\hline CKF & 4.74 & $1.22-18.30$ & 0.02 \\
\hline Killip 3 or 4 & 2.59 & $0.61-10.96$ & 0.20 \\
\hline Ventilatory support (MV) & 3.64 & $1.07-12.37$ & 0.04 \\
\hline Arrhythmia severe & 4.64 & $1.26-17.03$ & $<0.001$ \\
\hline Bleeding & 1.43 & $0.16-12.49$ & 0.74 \\
\hline Sepsis & 13.26 & $1.32-12.45$ & $<0.001$ \\
\hline
\end{tabular}

CHF: congestive heart failure; CKF: chronic kidney failure; MV: mechanical ventilation; $95 \% \mathrm{Cl}$ : confidence interval of $95 \%$.

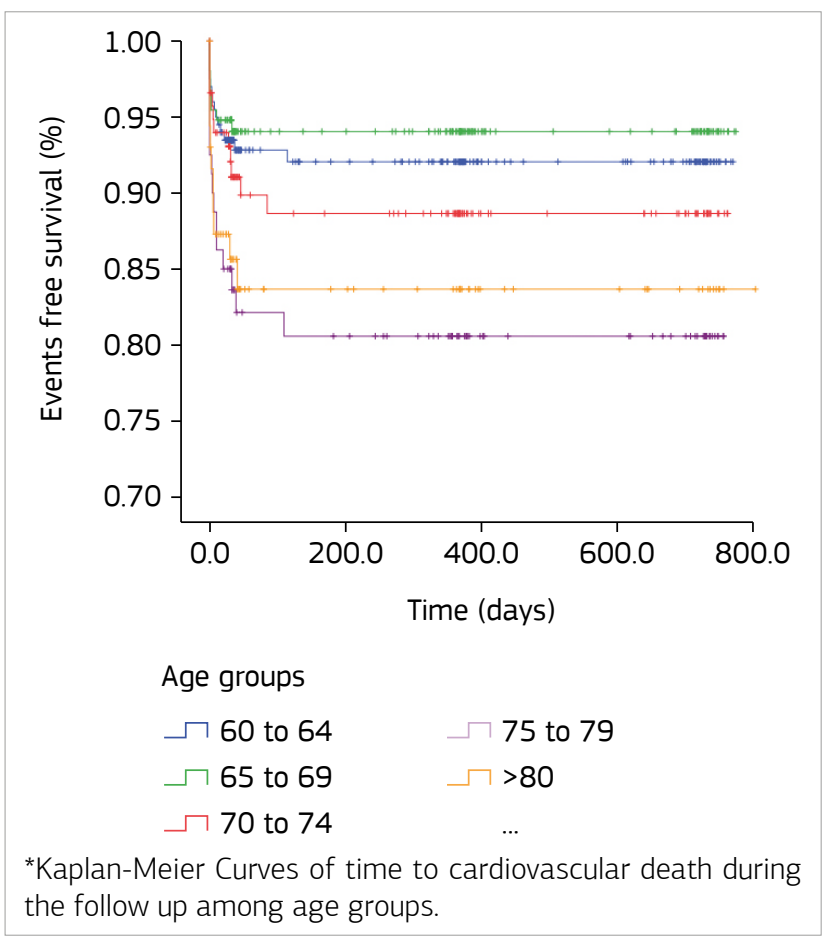

Figure 1 Survival curves by age group*. adoption of the radial approach, ${ }^{13}$ stent implantation techniques and improvements in drug-eluting stents technology. ${ }^{14}$ Recently, in a sub-study of the AIDA STEMITRIAL, ${ }^{15}$ there were no differences in angiographic success between patients with multivessel coronary disease vs. single-vessel disease in both groups. Thus, technical and personnel improvement in these 10 years may contribute to better angiographic success of older patients.

The AIDA STEMI study ${ }^{15}$ also demonstrated that patients over 75 who underwent primary percutaneous coronary intervention had the same frequency of renal failure as those who did not undergo pPCI. Thus, we can consider that this complication is probably not only due to contrast-induced nephropathy (CIN). Ischemia of renal tissues and reduced glomerular filtration may be the primary pathophysiologic components, and hydration and reduced contrast volumes are considered the most effective methods for prevention of CIN. ${ }^{16}$ Regarding in-hospital evolution, older patients had more AKI, which increased mortality. However, when AKI was added to the multivariate model, the 1-year increase in mortality was not significant. ${ }^{17}$

In this study the multivariate analysis showed that besides age $\geq 75$ years, the independent predictors of mortality also included chronic renal failure, severe arrhythmia, sepsis, and need for ventilatory support. We emphasize that these predictors are related to prior histories of patients, since, for example, the most common causes of arrhythmia are coronary disease, valve disease, and heart failure. Considering sepsis, in a previous study, we demonstrated that among the $3.9 \%$ of patients who had infections, $2 \%$ were community acquired - i.e., contracted before hospital admission. ${ }^{18}$

Door-to-balloon time was longer for patients over 80 years, but within the limit set out in the guidelines. It should be pointed out that the care teams and operation teams had the same technical training, so this longer time may be due to anatomic conditions associated with more difficult procedures, such as calcification, more diffuse disease, and tortuosity.

Similarly, there was no difference in relation to medications used, with the exception of glycoprotein IIb/ IIIa inhibitors, which were less frequently used among older patients. However, as previously reported, the use of IIb/IIIa inhibitors increases the rates of hemorrhagic complications. Nevertheless, older adutls present a slightly elevated risk of these complications. ${ }^{19}$ Therefore, the potential benefits of treating this population should be considered.

Our study has certain limitations that merit mention. Although our institution performs a very high volume of 
primary percutaneous coronary intervention procedures, this is still a single-center study that enrolled a modest number of patients. Patients' prior histories were taken by interviewing the patients themselves, so there may be information bias. Information on late clinical follow-up was collected both by electronic medical records and telephone interviews with patients and family members, which could also generate information bias.

\section{CONCLUSIONS}

In conclusion, we consider that primary percutaneous coronary intervention in patients over the age of 60 is a safe procedure providing high success rates. The independent predictors of mortality in this population were chronic kidney injury, need for ventilatory support, sepsis, and severe arrhythmia while still in hospital.

\section{CONFLICT OF INTERESTS}

There are no conflicts of interests to declare.

\section{FUNDING}

This project competed and won tax-deductible donations received from taxpayers who donated, through Law No. 12,213 of January 20, 2010, to the Municipal Fund for the Older Adults (Fundo Municipal do Idosos) and the Municipal Committee for the Older Adults (Conselho Municipal do Idoso), Porto Alegre, state of Rio Grande do Sul.

\section{REFERENCES}

1. Miranda GMD, Mendes ACG, Silva ALA. O envelhecimento populacional brasileiro: desafios e consequências sociais atuais e futuras. Rev Bras Geriatr Gerontol. 2016;19(3):507-19. http://dx.doi.org/10.1590/180998232016019.150140

2. Siqueira ASE, Siqueira-Filho AG, Land MG. Análise do impacto econômico das doenças cardiovasculares nos últimos cinco anos no Brasil. Arq Bras Cardiol. 2017;109(1):39-46. https://doi.org/10.5935/ abc.20170068

3. Brasil. Ministério da Saúde. Cadernos de Informação de Saúde. Mortalidade [Internet]. Brasil: Ministério da Saúde; 2016 [Accessed in Sep 21, 2018]. Available from: http://tabnet.datasus.gov.br/cgi/ deftohtm.exe?sim/cnv/obt10uf.def

4. Leistner DM, Münch C, Steiner J, Erbay A, Riedel M, Gebhard CMD, et al. Impact of acute kidney injury in elderly ( $\geq 80$ years) patients undergoing percutaneous coronary intervention. Interv Cardiol. 2018;31(6):792-8. https://doi.org/10.1111/joic.12547

5. Alexander KP, Newby LK, Armstrong PW, Cannon CP, Gibler WB, Rich $\mathrm{MW}$, et al. Acute coronary care in the elderly, part II: ST-segmentelevation myocardial infarction: a scientific statement for healthcare professionals from the American Heart Association Council on Clinical Cardiology. Circulation. 2007;115(19):2570-89. https://doi.org/10.1161/ CIRCULATIONAHA.107.182616

6. Forcadell MJ, Vila-Córcoles A, Diego C, Ochoa-Gondar O, Satué E. Incidence and mortality of myocardial infarction among Catalonian older adults with and without underlying risk conditions: The CAPAMIS study. Eur J Prev Cardiol. 2018;25(17):1822-30. https:// doi.org/10.1177/2047487318788396

7. Kvakkestad KM, Sandvik L, Andersen GO, Sunde K, Halvorsena S. Long-term survival in patients with acute myocardial infarction and out-of-hospital cardiac arrest: A prospective cohort study. Resuscitation. 2018;122:41-7. https://doi.org/10.1016/j.resuscitation.2017.11.047

8. Xu M, Yan L, Xu J, Yang X, Jiang T. Predictors and prognosis for incident in-hospital heart failure in patients with preserved ejection fraction after first acute myocardial infarction: An observational study. Medicine. 2018;97(24). https://doi.org/10.1097/MD.0000000000011093

9. Brasil. Ministério da Saúde. Estatuto do Idoso. 2ª ed. Brasília: Editora do Ministério da Saúde; 2009.

10. Piegas LS, Timerman A, Feitosa GS, Nicolau JC, Mattos LAP, Andrade MD, et al. V Diretriz da Sociedade Brasileira de Cardiologia sobre tratamento do infarto agudo do miocárdio com supradesnível do segmento ST. Arq Bras Cardiol. 2015;105(2):1-121.

11. Levine GN, Bates ER, Bittl JA, Brindis RG, Fihn SD, Fleisher LA, et al. 2016 ACC/AHA Guideline Focused Update on Duration of Dual Antiplatelet Therapy in Patients With Coronary Artery Disease. J Am Coll Cardiol. 2016;68(10):1082-115. https://doi.org/10.1016/j.jacc.2016.03.513

12. Gharacholou SM, Lopes RD, Alexander KP, Mehta RH, Stebbins AL, Pieper $\mathrm{KS}$, et al. Age and outcomes in ST-segment elevation myocardial infarction treated with primary percutaneous coronary intervention: findings from the APEX-AMI trial. Arch Intern Med. 2011;171(6):559-67. https://doi.org/10.1001/archinternmed.2011.36

13. Quadros AS, Schmidt MM, Gazeta CA, Melleu KP, Azmus AD, Teixeira JV et al. Infarto Agudo do Miocárdio na Prática Clínica Diária. Int J Cardiovas Sci. 2016;29(4):253-61. https://doi.org/10.5935/2359-4802.20160053

14. Lee DH, de la Torre Hernandez JM. The Newest Generation of Drug-eluting Stents and Beyond. Eur Cardiol. 2018;13(1):54-9. https:// doi.org/10.15420/ecr.2018:8:2

15. de Waha S, Eitel I, Desch S, Fuernau G, Pöss J, Schuler G, et al. Impact of multivessel coronary artery disease on reperfusion success in patients with ST-elevation myocardial infarction: A substudy of the AIDA STEM trial. Eur Heart J Acute Cardiovasc Care. 2017;6(7):592-600. https:// doi.org/10.1177/2048872615624240

16. Pan HC, Wu XH, Wan QL, Liu BH, Wu XS. Analysis of the risk factors for contrast-induced nephropathy in over-aged patients receiving coronary intervention. Exp Biol Med (Maywood). 2018;243(12):970-5. https://doi.org/10.1177/1535370218799973

17. Farhan S, Vogel B, Baber U, Sartori S, Aquino M, Chandrasekhar J, et al. Calculated Serum Osmolality, Acute Kidney Injury, and Relationship to Mortality after Percutaneous Coronary Intervention Cardiorenal Med. 2019;9(3):160-7. https://doi.org/10.1159/000494807

18. Oliveira PP, Gonzales V, Lopes RD, Schmidt MM, Garofallo S, Santos RP, et al. Serious infections among unselected patients with ST-elevation myocardial infarction treated with contemporary primary percutaneous coronary intervention. Am Heart J. 2016;181:52-9. https://doi. org/10.1016/j.ahj.2016.08.005

19. Germing A, Bojara W, Lawo T, Ewers A, Grewe P, Mügge A, et al. Bleeding complications associated with glycoprotein Ilb/llla inhibitors in patients 80 years of age and older undergoing percutaneous coronary intervention. Exp Clin Cardiol. 2010;15(3):e57-e60. 